\title{
Much Ado about Not-Very-Much?
}

\section{Assessing Ten Years of German Citizenship Reform}

\author{
Simon Green
}

Forthcoming in Citizenship Studies 16/2 (2012)

Contact Address:

Politics and International Relations

Aston University

Birmingham B4 7ET

United Kingdom

Tel: 00441212043786

Email: s.o.green@aston.ac.uk 


\title{
MUCH ADO ABOUT NOT-VERY-MUCH? ASSESSING TEN YEARS OF GERMAN CITIZENSHIP REFORM
}

\author{
Simon Green
}

\begin{abstract}
$\underline{\text { Abstract: }}$
This article examines the development and impact of German citizenship policy over the past decade. As its point of departure, it takes the 2000 Citizenship Law, which sought to undertake a full-scale reform and liberalisation of access to German membership. The article discusses this law's content and subsequent amendments, focusing particularly on its quantitative impact, and asking why the number of naturalisations has been lower than originally expected. The article outlines current challenges to the law's structure and operation and identifies potential trajectories for its future development.
\end{abstract}

Keywords: Germany, citizenship, naturalisation, jus soli, jus sanguinis, dual citizenship

\section{Introduction}

Over the past twenty years, the study of citizenship in the developed world has been enriched by a major new sub-field: the analysis and explanation of patterns of and policies towards the acquisition of membership, both at birth and via naturalisation. The corpus of scholarship in this area is now substantial and nuanced, and in the context of European nation-states encompasses a wide range of aspects, including comparative empirical analyses (e.g. 
Brubaker 1989, Hansen and Weil 2001, Bauböck et al. 2006), taxonomies of naturalisation regimes (e.g. Howard 2009) and detailed national case studies (e.g. Hansen 2000, Weil 2008, Green 2004).

Yet despite the wealth of scholarship on this area, the question of how access to nationality is structured politically, legally and philosophically remains as germane now as it has been at any time over the past two decades. This has two key reasons. First, and notwithstanding a 'postnational' turn in the 1990s (Soysal 1994, Sassen 1996, Jacobsen 1996) which held that globalisation and the widespread availability of social citizenship rights independently of membership rendered national citizenships irrelevant, nationality (still) matters. As Howard (2009, pp. 6-8) shows, certain rights of real significance, such as unconstrained residence and access to public sector employment, remain the exclusive preserve of full membership. Second, in the European context, national citizenship remains the sole route to the acquisition of citizenship of the European Union (EU). When combined with the growing chasm in rights between those who are EU citizens and so-called 'Third Country Nationals' (TCNs), the conditions under which the citizenship of an EU member-state can be gained are of direct relevance to the estimated 20 million TCNs resident in the EU in 2009. In consequence, the content, application and impact of individual national citizenship policies remain very much a live issue.

Over the course of these past twenty years, two distinct phases are conventionally identified in the evolution of citizenship policies in Europe (Joppke 2010, Chapter 2). First, during the 1990s, there was a broad liberalisation of access, as countries responded to the reality of permanent migrant communities in their territories. This took a number of forms, including the introduction of the territorial principle of ascription (jus soli) alongside the principle of 
descent (jus sanguinis) and the more widespread tolerance of dual and multiple citizenships (Vink and de Groot 2010). In fact, this led to an (uncoordinated) convergence of nationality policies in Europe (Hansen and Weil 2001, Bauböck et al. 2006). Since 2001, the emphasis has shifted clearly away from opening up access, albeit gradually and not uniformly throughout Europe, towards a 'thickening' of citizenship, with many countries successively introducing assimilatory elements such as language and citizenship tests, integration courses and citizenship ceremonies (Goodman 2010). Notably though, this changed emphasis has not necessarily come at the expense of numbers naturalised: as Howard (2009, p. 217) shows, between 1985-90 and 2000-05, naturalisation rates, which express the annual proportion of a country's non-national population acquiring citizenship, rose in eleven of fifteen EU memberstates.

Against this background, the aim of this article is to discuss the development of one national citizenship in particular, namely that of Germany. While broad cross-national comparisons help us to understand overall trends, it requires a detailed case study such as this to tease out the nuances and fine details of individual citizenship policies. And Germany constitutes a particularly interesting case study, for three main reasons. First and foremost, citizenship in Germany has conventionally been considered as the paradigmatic example of an 'ethnocultural' definition of citizenship (Brubaker 1992), with an associated high degree of exclusivity in terms of access for non-nationals. In practice, this meant that Germany relied exclusively on the principle of descent (jus sanguinis) for ascription at birth, with the territorial principle (jus soli) completely absent; as Kay Hailbronner, in one of the early discussions of German citizenship policy in English, asserted, 'the German conception of citizenship and nationhood is better expressed in the principle of jus sanguinis' (Hailbronner 1989, p. 77). In parallel, naturalisation was to be an exceptional act, which therefore justified 
high assimilatory requirements on the part of applicants, including long periods of residence, the payment of high fees and the rejection of dual and multiple citizenships (Green 2004, pp. 39-41). In consequence, the numbers of non-nationals actually becoming Germans remained negligibly low, and failed to rise above 20,000 throughout the 1970 s and 1980s, resulting in annual naturalisation rates of below 0.5 per cent throughout this time.

Second, the last full reform of German citizenship, which took place in 1999 and came into force on 1 January 2000, was of major symbolic and political significance. Its predecessor, the 1913 Reichs- und Staatsangehörigkeitsgesetz (RuStAG) had been on the statute books continuously since 1914. Not only did the law epitomise the then ethnocultural nature of German citizenship, having survived both the Weimar Republic and National Socialism to be adopted by West Germany (Brubaker 1992), but in doing so it also constituted a direct link between the new, unified Germany and the Third Reich. Politically, the law represented the culmination of a protracted process spanning almost twenty years (Green 2004). Even the law's passage through parliament during 1999 had been marred by controversy, when the conservative CDU ran its now notorious petition campaign against the SPD-Green federal government's original plans to allow dual citizenships on an unrestricted basis (Howard 2008, pp. 46-52). Given that in 2010 the law had been in force for ten years, this article takes this opportunity to assess the law's subsequent evolution and impact in practice.

But the third reason for looking at Germany is arguably the most significant: at almost 6.7 million persons in 2009 , Germany is home to by far the largest non-national population in the EU. ${ }^{1}$ By definition, therefore, naturalisation and citizenship policy matters. What is more, almost two-thirds of this total, or 4.3 million persons, are TCNs, including some 1.7 million Turkish nationals. Given that, therefore, over one-fifth of all the EU's TCNs reside in 
Germany, its provisions for and practice of citizenship acquisition is a key determinant of access to EU citizenship and the associated rights for this group.

This article proceeds as follows. It begins by briefly sketching out the content of the 2000 law, before discussing subsequent amendments to it, with particular emphasis on reforms in 2004 and 2007. It then discusses the law's quantitative impact, and asks why this has been much lower than had originally been anticipated. Subsequently, the article moves to outlining some of the other issues which have emerged in citizenship policy before concluding with some thoughts on the future direction of German citizenship in the twenty-first century.

\section{The content of Germany's 2000 Citizenship Law}

Although it technically constituted an amendment of the RuStAG rather than a complete new piece of legislation, there can be little doubt that the 2000 law (or Staatsangehörigkeitsgesetz) fundamentally reformed access to German citizenship in three key ways (cf. Green 2000). First, while the three principal established routes to naturalisation, via state discretion (Ermessenseinbürgerung), marriage to a German national or legal entitlement (Anspruchseinbürgerung), were retained together with their respective requirements, the 2000 law practically halved, from fifteen to eight years, the residence period required in order to qualify for the latter. The importance of this reduction should not be underestimated, as over two-thirds of all naturalisations fall under the category of legal entitlement, compared to less than 15 per cent for the other two categories combined (Worbs 2008, pp. 19-20). Moreover, with almost two-thirds of the non-national population in 2000 having residence periods of over eight years, compared to 40 per cent with over fifteen years, the potential population 
eligible for naturalisation, at least in terms of residence periods, increased at a stroke by more than half. ${ }^{2}$

Second, the law introduced jus soli for the first time in the history of German citizenship. Hitherto, the exclusive reliance on jus sanguinis meant that successive generations of migrants' descendants were born in Germany without automatic access to full citizenship rights; in 2009, they accounted for almost one-fifth of the total non-national population. However, from 2000, all children of non-nationals where one parent had eight years' residence and was in possession of a permanent residence status became German at birth. Over and above this, the law also provided for a transitional arrangement granting children born after 1 January 1990, i.e. 10 years before the new citizenship law came into force, the right to register as German nationals under the same conditions. Lastly, although the law continued Germany's long tradition of rejecting dual citizenship in naturalisations, it introduced some new exceptions to this rule, covering recognised refugees, the over 60 s and nationals of certain EU member-states (see below).

However, these liberalisations were not as unequivocal as they seemed at first sight. Most of all, the introduction of jus soli was in reality closely circumscribed. Thus, the requirement for one parent to hold a permanent residence status has proved to be a highly significant barrier, as it excludes the comparatively high proportion of non-nationals living in Germany with only a temporary residence status. In consequence, only around half of all children born annually to non-national parents in the country actually qualify for jus soli (see figures in Beauftragte der Bundesregierung 2007, p. 215, also Green 2000, p. 114). Furthermore, and as a direct response to the CDU's highly successful petition campaign in 1999 against multiple nationalities, the 2000 law stipulated that the dual citizenships created by jus soli should only 
be temporary, with beneficiaries having to opt-in to German nationality through obtaining release from the other by the age of twenty-three, or else face loss of their German passports (the so-called Optionsmodell). This is a point of major significance which will be returned to below.

Moreover, in other areas, the law actually imposed new, more restrictive standards. The fees for naturalisation were raised fivefold from the equivalent of $€ 51$ to $€ 255$. A loophole in the RuStAG which had allowed especially Turkish nationals who had become Germans to then obtain dual citizenship by afterwards renaturalising as Turks, was also closed. Lastly, the law also laid down new requirements for (otherwise unspecified) German language competence as well as excluding those applicants from citizenship where concrete suspicions (tatsächliche Anhaltspunkte) cast doubt on their willingness to conform to Germany's constitutional order (freiheitlich demokratische Grundordnung) - a provision targeted at applicants with extremist political tendencies.

This mixture of liberalisations and restrictions has led to a (not entirely surprising) divergence in the law's assessment by politicians and scholars. For instance, in the final parliamentary debate on the law in May 1999, Interior Minister Otto Schily praised the reform as 'historic', and the Green politician Cem Özdemir, himself the naturalised son of Turkish immigrants, concluded that 'on 1 January 2000, this country will gain a new, modern, republican and European citizenship law' (Deutscher Bundestag Plenarprotokoll 14/40, pp. 3415, 3425). ${ }^{3}$ Interestingly, this has set the tone for the subsequent presentation of the law by successive governments, even those led by the CDU/CSU: most recently, the federal government began its written reply to an enquiry (Große Anfrage) by the Left Party on citizenship policy in June 
2009 by declaring that 'Germany has an open and modern naturalisation law' (Bundestagsdrucksache 16/13558, p. 3).

By contrast, the response of scholars across the world has been somewhat muted. Certainly, there is a widespread consensus that German citizenship can no longer be deemed ethnocultural in its essence. Already, Hansen and Koehler (2005), Joppke (1999) and Hagedorn (2001) note that the introduction of legal entitlements to naturalisation in 1993 constitutes an early break with ethnoculturalism. In the law itself, the introduction of jus soli is considered a 'seismic shift' (Green 2000, p. 114), while Palmowski concludes that 'both in the principle of jus soli, and in the extended practice of dual citizenship, the ethnocultural ideal of nationhood that still featured so strongly in Brubaker's work has been decisively breached' (Palmowski 2008, p. 560; see also Howard 2005, pp. 711-712).

However, a number of caveats are clearly identified. Several scholars (e.g. Howard 2008, pp. 55-58, Klusmeyer and Papademetriou 2009, p. 204) have pointed to the limited quantitative impact of the new law, an issue which will be returned to below, while Davy (2005, p. 142) concludes that "even after the changes enacted in [2000], German nationality law does not meet the sentiments and preferences of long-term immigrants'. Others have pointed out that, by formally continuing to reject dual nationality for non-nationals while simultaneously accepting it without qualification among ethnic German immigrants (Spätaussiedler), German citizenship retains 'more than a whiff of ethnocultural exclusivity' about it (Green 2005, p. 948). 
Although the 2000 law was indisputably a major piece of legislation, its content soon came under political scrutiny again, leading to two sets of amendments in 2004 and 2007 which focused on the Citizenship Law's new assimilatory elements requirements for naturalisation. The first occurred in 2004, in the course of the formulation of Germany's first immigration law (the Zuwanderungsgesetz). As a result, not only were the various provisions for citizenship, which had since 1990 been spread over two separate pieces of legislation, consolidated into the single Staatsangehörigkeitsgesetz, but Germany's myriad residence titles were reduced into effectively two, one temporary and one permanent, thereby simplifying access to jus soli. In addition, the standard residential requirement for naturalisation by legal entitlement was reduced from eight years to seven for those applicants who had completed the new integration courses introduced by the Zuwanderungsgesetz. On the question of assimilatory requirements, the political compromise around the Zuwanderungsgesetz also included that henceforth all applications for naturalisation should be referred to the federal internal security service (Bundesverfassungsschutz) for checking.

Meanwhile, a range of other issues, some practical, some political, had emerged in citizenship policy. Initially, as part of the post-2000 naturalisation procedure, all applicants had to sign a rather convoluted declaration of constitutional loyalty (see text in Spindler 2002, p. 67). In parallel, several cities, on their own initiative although often encouraged by the respective Land government, started from 2001 to present naturalisation certificates in the context of formal citizenship ceremonies, rather than simply handing them over in the anonymous environment of an office, thereby reflecting (independently) the practice which was emerging in other European countries such as the UK. Many municipalities wanted to offer a positive conclusion to the process of naturalisation (Topçu 2007, pp. 58-61); in doing so, they have 
provided a contrast to the rather defensive nature of the referral of applications to the security service and the declaration of constitutional loyalty.

A second issue concerned the automatic toleration of dual citizenship in applicants from certain EU member-states. In the 2000 law, this was limited to countries where reciprocity could be established, such as Sweden and the UK. In principle, this left little room for interpretation by the 16 federal states, who in Germany are responsible for implementing federal policy. However, Bavaria and Baden-Württemberg, two conservative states where political opposition to dual citizenship is particularly deeply engrained, refused to recognise this principle. In 2004, this divergence from national law was struck down by the Federal Administrative Court, but even after this, Bavaria continues to reserve the right to check whether reciprocity in individual cases is in fact guaranteed (Hofhansel 2008, pp. 180-181, Topçu 2007, p. 49).

The third area concerned the provision for 'adequate competence' in the German language introduced in the Staatsangehörigkeitsgesetz. Both the law itself and the accompanying secondary legislation (Allgemeine Verwaltungsvorschriften) left unspecified what constituted 'adequate' language skills and how these might be established. In consequence, the Länder as implementing agencies interpreted this provision as they saw fit, leading to considerable divergence in practises (see the breakdown in Bundestagsdrucksache 16/13558, pp. 29-31). To complicate matters further, the integration courses introduced by the Zuwanderungsgesetz in 2005 for new and existing non-national migrants set a higher target for language competence, namely level B1 in the Common European Framework of Reference for Languages (CEFR), than was demanded by most Länder for naturalisation. 
The fourth topic to emerge was arguably the most controversial. In early 2006, it emerged that two federal states, Baden-Württemberg and Hesse, had introduced different supplementary tests for naturalisation candidates. Baden-Württemberg's was undoubtedly the more contentious: it had chosen to complement its security checks with a series of hypothetical questions to be put by officials to applicants in an interview in an attempt to elicit their values and attitudes on a range of issues, including terrorism, equal rights and homosexuality. But what caused the most concern was the fact that the questions were only to be employed in cases where the applicants were Muslim (Migration und Bevölkerung 1/2006, pp. 1-2, also Joppke 2007, p. 15). Soon after, the state of Hesse introduced a knowledge-based naturalisation test, of the kind employed by the United States and Canada and now used by the UK and the Netherlands. A lively public and political debate ensued, at the end of which the Länder agreed to harmonise naturalisation procedures around a Hesse-style test.

Together, these four areas were incorporated into a second reform, which came into effect in early 2007 and which therefore constitutes the altogether more significant of the two post2000 amendments to citizenship policy: ${ }^{4}$

- As a rule, applicants for naturalisation are now required to demonstrate German language skills at Level B1 GER or its equivalent, for instance a school leaving certificate. As an incentive, the residential requirement for applicants with high levels of integration, for instance language skills at B2 GER, is reduced to six years.

- In order to demonstrate knowledge of German society, the 2007 reform required applicants to pass a harmonised naturalisation test, which was introduced with effect from 1 September 2008. In the test, which costs $€ 25$ to sit and can be repeated indefinitely, candidates have to answer 33 out of a possible 330 multiple-choice 
questions, with 17 correct responses required to pass. Any applicant who has successfully completed school in Germany is exempted.

- In Section 16, the revised law supplemented the (now amended) written statement of loyalty with an aural declaration to be made at the time of the presentation of the naturalisation certificate.

- Lastly, in Section 12 (2), the post-2007 law now automatically permits dual citizenship for all applicants from EU member-states and Switzerland.

But the 2007 reforms also included two additional changes, each of which has in fact served to raise the bar for naturalisation. First, the existing provision that applicants should be free of criminal convictions was amended. Ever since this had been introduced in 1990, sentences of up to six months' prison or an equivalent fine (Tagessätze) did not exclude candidates from naturalisation. However, post-2007, under Section 12a of the Staatsangehörigkeitsgesetz, the limit has been halved to three months, and offences will now be counted cumulatively, not individually.

Even more significant though is a change affecting those non-nationals aged between 18 and 23: hitherto, they were excluded from the requirement in Section 10 to provide for themselves and their dependants. This has now been removed, thereby adding a potentially major exclusionary hurdle: given that non-nationals in Germany have disproportionately low education and high unemployment outcomes, the chances of applicants in this age group being able to support themselves financially are in all likelihood slight.

Cumulatively, it is not unreasonable to conclude that the changes in 2004 and 2007 add up to a significant tightening of the 2000 law, which itself was not quite as liberal as had initially 
been claimed. The article therefore turns to consider the law's quantitative impact before discussing some of the reasons behind this and identifying some of persistent problem areas in its operation.

\section{Where have all the naturalisations gone?}

One of the stated aims of the 2000 reform was to increase the take-up of German citizenship in quantitative terms. In his first statement of governmental policy (Regierungserklärung) on 10 November 1998, Chancellor Gerhard Schröder spelled this out: 'This government will modernise the law on nationality. That [sic] will enable those living permanently in Germany and their children born here to acquire full rights of citizenship' (official translation, cited in Howard 2008, p. 49). And there seemed to be every reason to expect this goal to be fulfilled: in his initial analysis of the new law, the late Günter Renner confidently predicted that, if nothing else, it would result in a significant increase in numbers of naturalisation (Renner 1999, p. 163).

However, the reality has been somewhat different: as Figure 1 shows, following an initial surge in 2000 , the absolute numbers of naturalisations have shown a steady decline over a tenyear period.

(Figure 1 about here) 
The extent and severity of this reduction should not be underestimated. Since 2000, naturalisations have halved and since 2008 have stood below the symbolic 100,000 mark. Moreover, for comparison, Figure 1 also provides naturalisation figures during the 1990s: it is notable that since 2008, naturalisation numbers have fallen below 1998 levels. What this means is that the current law, with its self-declared modernity and openness, is actually helping to create fewer new citizens than the old, supposedly more restrictive law.

This development is even more stark when the development of naturalisations among the Turkish population, by far the largest non-national group in Germany, is considered. In fact, the number of naturalisations of Turks peaked at 104,000 in 1999, before the new law came into force. This was due to a technicality: at that time, each applicant for release from Turkish citizenship had to be individually countersigned by the Turkish Prime Minister, leading to a huge backlog which happened to be cleared in that year (Green 2004, p. 80). But since then, the drop in Turkish naturalisation has been nothing short of dramatic: in 2008 and 2009, the number had fallen to under 25,000, representing a fall from 1999 of over 75 per cent (Statistisches Bundesamt 2010, p. 13).

In comparison with other EU member-states, too, Germany does not fare well. Between 2000 and 2007, the annual naturalisation rate in Germany fell from 2.6 per cent to 1.6 per cent. By contrast, in all other countries with large non-national populations in the EU, such as the UK, France, Belgium, the Netherlands and Sweden, the naturalisation rate was considerably higher. Even Austria, traditionally one of the most stringent countries in terms of naturalisations, returned naturalisation rates which have consistently been higher than in Germany (see figures in Bundestagsdrucksache 16/13558, p. 51). 
However, perhaps the most telling comparison is between numbers of naturalisations, which have been falling, and the average residence period, which has been rising steadily: whereas it stood at 9 years in 1980, it had risen to 16 years in 2003, 17 years in 2006 and 19 years in 2009. If Germany's citizenship policy were to be effectual in terms of meeting its stated aim of increasing naturalisation, that figure would need to have fallen, as those non-nationals who fulfil the residence requirements gradually become citizens and their statistical exit from the ranks of non-nationals thereby brings the overall average down. In reality, the rising average residence period indicates that the opposite is occurring. This trend is confirmed by official calculations of the take-up rate for naturalisation, expressed as a proportion of those eligible in terms of both residence period and status (Statistisches Bundesamt 2010, p.15). The results are equally meagre: thus, the take-up rate declined by over half from its peak of 3.95 per cent in 2000 to just 1.9 per cent in 2009 . What this suggests is that while a priori eligibility for naturalisation is rising, an increasing number of long-term resident non-nationals are choosing not to naturalise.

Of course, the key question arising from this is why this should be the case and what reasons underlie this trend. This is undoubtedly a complex issue and difficult to answer with certainty, but a number of potential factors can be identified. First, because of the introduction of jus soli and the associated transitional arrangement, large numbers of children who might otherwise have naturalised with their parents (thereby adding to the total figure) now automatically hold German citizenship, at least for the time being (Lämmermann 2009). Indeed, Worbs' analysis (2008, pp. 27-28) shows that between 2000 and 2007, over 355,000 persons obtained German citizenship via this route, with post-2000 births accounting for 86 per cent of the total. 
Second, EU nationals, who account for roughly a third of all non-national residents in Germany, have shown a particularly low propensity to naturalise. As the Statistisches Bundesamt's figures (2010, pp. 18-19) show, their take-up rate between 2002 and 2009 varied from 0.6 per cent in 2002 to 1.0 per cent in 2004 , before gradually falling back to 0.8 per cent in 2009. In a way, this is a rather unexpected development, given the extensive concessions made to EU nationals, in particular the automatic toleration of dual citizenship after 2007. Instead, this probably reflects the comprehensive availability of welfare and residential rights, as well as partial availability of political rights (at local and EU level) for EU citizens, which has rendered any material gain from naturalisation for this group effectively meaningless.

A third possibility is that the cumulated restrictions introduced in 2005 and 2007/8 are deterring many would-be applicants from citizenship. Certainly, the raising of the bar in the necessary language skills appears anecdotally to have caused some difficulties (details in Lämmermann 2009, pp. 292-293). Likewise, it cannot be discounted that the very existence of the naturalisation test has put some applicants off, even though in practice it presents little difficulty to those taking it: the pass rate between 1 September 2008 and 31 March 2009 was 98.7 per cent nationally (Bundestagsdrucksache 16/13558, p. 53). Meanwhile, Howard (2008, p. 56) is sceptical of the notion that the fivefold increase of fees in 2000 may have deterred applicants, pointing to the fact that internationally Germany, in this respect at least, remains firmly in the mid-range of countries. In the past, there have also been a range of factors specifically affecting Turkish applicants for naturalisation. In the 1980s, becoming German would have meant losing inheritance rights in Turkey; likewise, many young male Turks were at that time faced with making considerable payments to release them from the obligation of military service in Turkey. But these issues have all long been dealt with from the Turkish side and even the process of release from Turkish citizenship, which constituted a very real 
impediment up until the late 1990s (see above), has now been streamlined and is relatively unproblematic. Taking these factors together, it is difficult to conclude with any certainty that there is an inverse relationship between the requirements for naturalisation and the numbers of naturalisations actually achieved.

In truth, when accounting for falling naturalisation numbers, the real 'elephant in the room' is, as it has for decades, Germany's continued formal rejection of dual citizenship in naturalisations (cf. Green 2005). That is not to say that the Staatsangehörigkeitsgesetz has not had a significant impact in this area. In particular, the now automatic acceptance of dual citizenship for refugees has led to a sharp increase in the proportion of naturalisations where multiple nationalities are tolerated. As Figure 2 shows clearly, the introduction of the new law in 2000 led to a jump in the rate of acceptance of dual citizenship, which since 2006 has exceeded 50 per cent. However, this global figure hides considerable variation by nationality: in 2008 and 2009, the toleration rate for Turkish nationals, who still account for about 25 per cent of all naturalisations, stood at a much lower 18 per cent and 23 per cent respectively. By contrast, for Afghan nationals, almost all of whom will be recognised refugees, the toleration rate is close to 100 per cent.

(Figure 2 about here)

In fact, the real problem lies not in the relatively generous level of toleration, but in the emotional break that being released from one's citizenship of birth can entail, as well as in the inconvenience and cost which applicants are expected to shoulder in seeking this release. For 
instance, dual citizenship is also tolerated when the home country does not in principle release its citizens from their nationality. However, in 2009, the interim secondary legislation listed just nine countries where this is the case: Afghanistan, Algeria, Eritrea, Iran, Cuba, Lebanon, Morocco, Syria and Tunesia (Bundesministerium des Innern 2009, p. 34). In all other cases, applicants are expected to attempt to obtain release from their citizenship. Elsewhere, under Section 12 of the citizenship law, dual citizenship is generally accepted if the home country does not release the applicant within a 'reasonable' timescale, if release is linked to 'unreasonable' conditions or if release brings with it 'significant' financial costs. Here too, the interim secondary legislation spells out just what is considered to be 'reasonable' (Bundesministerium des Innern 2009, pp. 35-36): thus, if necessary, applicants are expected to spend up to two-and-a-half years obtaining release, pay fees connected to the release process of up to $€ 1,278.23$ and bear general financial disadvantages up to the value of $€ 10,225.84$ - all in the name of becoming German citizens. It does not seem unreasonable to conclude that some applicants for naturalisation end up paying a considerable price in order that Germany can maintain its principled opposition to dual citizenship.

Given the emotional, practical and financial costs involved, it is scarcely surprising that interest among non-nationals in obtaining German citizenship is overall low. Worbs (2008, pp. 28-38) provides a detailed analysis of data from the Socio-Economic Panel (SOEP) on this question. This shows that in period from 1996 to 2006, interest in obtaining German citizenship did increase up to 2000 before dropping off again afterwards; however, the proportion of respondents whose intention to naturalise was 'definite' or 'probable' peaked at just 30 per cent in 2000, and by 2006 had fallen back to around 20 per cent. In terms of age groups, interest is highest among the 15-24 age group and then wanes considerably with age. In particular, Worbs' analysis demonstrates clearly that the desire to retain one's citizenship is 
the principal reason why both Turks and the citizens of former Yugoslavia, the two largest national groups among Germany's immigrants, choose not apply for naturalisation. What is more, the second most important reason is that their residence is already secure, indicating that these two national groups see little material advantage in becoming German.

Overall, given its initial aim, it is clear that the 2000 law has been a disappointment in quantitative terms and falls well short of the high expectations invested in it at the time of legislation. Although the number of naturalisations actually showed a slight increase between from 2008 to 2009 , it is far too early to say whether this constitutes a temporary blip, a levelling off or even a reversing of the long-term trend. While the comparatively large number of citizenships via jus soli offers some consolation, this is tempered by the fact that around half of children born to non-national parents in Germany do not benefit from this facility. In addition, research has shown that the bureaucratic upheaval associated with naturalisation leaves many new German citizens jaded and disillusioned by the entire experience (Wunderlich 2005) - arguably the exact opposite of what would be desired. Lastly, by now requiring all applicants, even those between the ages of 18 and 23, to be able to provide for themselves and their dependants financially, the 2007 reforms have, deliberately or otherwise, raised the bar for precisely the group of non-nationals who have the highest level of interest in becoming German.

\section{Other issues and challenges}

As Germany's revised citizenship law enters its second decade, its relatively low quantitative impact is not the only challenge it faces, as four main technical and administrative issues have 
also become apparent, some of which will have a significant bearing on the future direction of citizenship policy.

First and foremost of these is the future of the Optionsmodell, under which the over 350,000 beneficiaries of jus soli to date will have to opt-in to German citizenship by obtaining release from their other citizenship by the age of 23, or face loss of their German passport. In 2008, the first of the cohort naturalised under the transitional arrangement, which included those born in 1990, turned 18. By 2013, therefore, they will have to choose either their German or their other citizenship. In 2018, the first Germans qua jus soli proper will reach the age of majority, and by 2023 they too will have to choose one or the other. While limitations of space preclude a more detailed discussion of this problem, the constitutionality of this provision is hotly contested, and the issue is certain to end up before the Federal Constitutional Court, probably within the next five years.

A second issue concerns the persistence of quite widespread variation between the individual Länder as implementing agencies in terms of the standards applied and outcomes in terms of naturalisation rates (Worbs 2008, pp. 21-22). Thus in 2007, Schleswig-Holstein, RhinelandPalatinate and Bremen, all states with SPD Interior Ministers, had the highest naturalisation rates. By contrast, the more conservative states of Bavaria and Baden-Württemberg had the lowest naturalisation rates in the western part of the country, where around 95 per cent of non-nationals live. A similar picture emerges when toleration of dual nationality in 2007 is taken into consideration (see Bundestagsdrucksache 16/13558, pp. 31-32): SchleswigHolstein and Rhineland-Palatinate again top the list, with Bavaria and Baden-Württemberg among the lowest. However, the picture is not as clear as it might initially seem. In 2007, Berlin and Bremen, both states with SPD-led governments, had the lowest toleration of dual 
nationality; likewise, Hesse, Lower Saxony and Northrhine-Westphalia, all with CDU-led governments, had above average naturalisation rates and toleration rates for dual citizenship. Instead, the size and composition of the respective Land's non-national population appears to be a better guide to likely outcomes in this area, although political leadership can still obviously play a role at the margins (Green 2005, pp. 931-932). More prosaically, the level of administrative resources available to a state in processing applications is also likely to affect outcomes in this area (Hagedorn, 2001, p. 172).

The third issue is related to the second and concerns the way the state administrative structures deal with applicants for naturalisation (Lämmermann 2009, pp. 295-296). All too often, would-be German citizens are confronted by a structurally conservative bureaucracy which is reluctant to recognise the commitment non-nationals are showing by the very act of applying for citizenship. For instance, the naturalisation authorities offer little in the way of advice and appear unwilling to interpret the existing regulations generously and in the interests of increasing naturalisations, as criticised by the federal government's Commissioner for Immigrants, Maria Böhmer, in a parliamentary answer in May 2009 (Deutscher Bundestag Plenarprotokoll 16/221, p. 24290). Perhaps surprisingly given the length of Germany's migration history, authorities at either state or municipal level have, with very few exceptions, also yet to adopt active strategies to advertise the possibility of naturalisation more widely.

Lastly, the Staatsangehörigkeitsgesetz is not an easy law to deal with. Its provisions are long, detailed and linguistically complex; this makes it difficult to relate the law to users and potential beneficiaries, who are of course overwhelmingly non-specialists. Moreover, since the 2007 reform, there has been a notable convergence in the conditions and standards laid down in the interim secondary legislation for naturalisation by state discretion, by marriage to 
a German citizen and by legal entitlement, to the extent that they are now practically the same (see Bundesministerium des Innern 2009). There is therefore a case to be made for future reforms consolidating the various paths to naturalisation under one heading of legal entitlement.

Fortunately, the picture is not all negative and there is one key area which promises positive developments in creating a more open German citizenship. Ironically, it is dual citizenship. Undoubtedly, this is not a question of formal provisions: given the entrenched political opposition of the CDU/CSU, there seems little prospect of Germany relinquishing its principled opposition to multiple citizenships any time soon. That said, Germany has since 2002 left the Council of Europe's 1963 Convention on the Reduction of Cases of Multiple Nationality in favour of the 1997 European Convention on Nationality, which adopts a more liberal approach to multiple citizenships (Howard 2005, p. 704). This removes one of the primary legal arguments against a more widespread acceptance of dual nationality in Germany.

Rather, the change will come by accretion. Already, descendants of bi-national parents (where one parent is German) generally inherit both citizenships permanently: between 2000 and 2007 , over 600,000 children were born into such bi-national marriages alone (Statistisches Bundesamt 2009, p. 57). ${ }^{5}$ Furthermore, between 2000 and 2009, some 626,000 persons have been naturalised with dual citizenship. Any children they have subsequent to obtaining German nationality will normally automatically gain both citizenships by descent. The Optionsmodell, if overturned by the Federal Constitutional Court, will end up almost doubling that figure. Even in its current form, the Optionsmodell may end up creating more dual nationals than was originally anticipated: as Dornis (2002, p. 172) notes, if those who have 
gained German citizenship through jus soli themselves have children before the age of 23 , their children will inherit this by descent and retain it even if the parent ultimately ends up losing their German citizenship. Similarly, the automatic toleration of dual nationality among other EU and Swiss nationals means that any descendants of this group who gain German nationality via jus soli will exempted from seeking release from one or the other citizenship by the time they reach the age of 23 . Although it is difficult to establish any reliable estimates on the number of dual nationals in Germany, what is certain is that their ranks will swell considerably over the next ten years as a result both of the 2000 law and the established principles of citizenship ascription in bi-national families. In turn, this raises the prospect that the political salience of dual nationality, which has hitherto been high, is neutralised simply by virtue of it being more common. And in the longer term, should Turkey ultimately realise its aspiration to become an EU member state, then Germany's rejection of dual citizenship becomes for all intents and purposes meaningless, as the single largest non-national group in the country would no longer be affected.

\section{Conclusion}

It is perhaps tempting to think that the challenge of access to citizenship in Germany is overstated. After all, Germany's multicultural team at the 2010 World Cup in South Africa included players of Polish, Ghanaian, Turkish and Brazilian ancestry; it thereby invited comparisons with France's famous 1998 Black, Blanc, Beur squad, which itself was seen as indicative of that country embracing its diversity. However, as this article has argued, the challenge of citizenship policy remains very much alive in Germany. It has shown that the liberalising elements of that law, principally the introduction of jus soli and the halving of the 
residential requirement, were accompanied by a range of new restrictions, which were further increased in the 2004 and especially the 2007 amendments. It has also analysed the quantitative trend in naturalisations over the past decade, finding that this has fallen far behind expectations and pinpointing Germany's continued rejection of dual citizenships (albeit with now numerous exceptions) as the primary reason behind this trend.

In doing so, the article shows that the development of Germany's citizenship policy is now clearly in step with the overall trend across the EU. With the increased focus on language tests as a precondition for naturalisation, flanked by the recent introduction of citizenship tests and ceremonies, there is broad convergence with what has become a more-or-less standard constellation of policy instruments in Europe (cf. Vink and de Groot 2010). Nonetheless, the analysis reiterates that important insights can be gained from the study of individual country cases. As this article has shown, the details of Germany's provisions for jus soli mean that it cannot easily be slotted into a given category; similarly, its approach to dual and multiple citizenships is more complex than simple opposition. Even a consideration of Germany's naturalisation rate does not capture the full impact of its citizenship policies across the board. Certainly, there are many specificities that could not be touched on here for reasons of space, especially those pertaining to the politics, ideology and identity of citizenship, and the reader is referred to the range of influential contributions which already exist on these questions (e.g. Klusmeyer and Papademetriou 2009, Palmowski 2008, Green 2005).

Overall, and for all the problems with the new law, it is worth remarking on the degree to which the historically high levels of naturalisation, which have now been sustained for a decade, have changed Germany. Between 2000 and 2010, over 1.3 million persons were naturalised, including almost 470,000 Turks. Added to this number are almost 400,000 
children and young people who between 2000 and 2008 received German citizenship, albeit temporarily, via jus soli. This estimated total exceeding 1.7 million over ten years compares with just 244,000 naturalisations between 1972 and 1989, and 926,000 in the 27 years between 1972 and 1999. This comparatively high total has also changed the electoral dynamics of citizenship: in a party system where recent federal elections have generally been close-run affairs, political parties have woken up to the fact that these large numbers of naturalised votes can make the difference between victory and defeat (on this topic, see Wüst 2004).

It is also worth returning briefly to the question of whether Germany, by virtue not of the content but of the relatively exclusive outcome of its citizenship law, retains an ethnocultural colouring in its definition of membership. Certainly, the cumulative impact of the 2000 reform, including in dual citizenship, has helped this colouring to fade further, although not as much as would have been the case had dual citizenship been accepted unequivocally. But an ethnocultural tinge was also provided by ethnic German immigrants (Spätaussiedler), whose privileged immigration conditions and automatic naturalisation, including full dual citizenship, created a situation where it was tempting to conclude that "ethnicity provides an edge that mere residence and payment of taxes does not' (Green 2000, p. 118, also Brubaker 1992, p. 170). This was of particular significance during the early 1990s, when the very high numbers of such immigrants (over 200,000 per annum between 1991 and 1995) inherently emphasised the contrast between membership of the ethnocultural group and outsiders. However, since the turn of the Millennium, numbers have begun to drop quite significantly, falling below 10,000 in 2006. In 2009, just 3,000 ethnic Germans and their dependants were arriving in Germany. In the light of such low migration, the notion of ethnocultural privilege quite simply loses its relevance. 
More broadly, there has been a palpable transformation in public discourse away from the rather binary division between 'Germans' and 'foreigners' (see Faist 1994) towards 'migration background' (Migrationshintergrund) as the defining characteristic (see Palmowski 2008 for a more thorough discussion of this shift). A key factor in this reorientation was the publication in 2005 of new census data (Mikrozensus), which showed that almost one person in five in Germany (and obviously much higher in urban areas) either themselves had a personal experience of migration or at least one parent or grandparent with a personal experience of migration - typically for reasons of work, asylum or as an ethnic German. This startling revelation has helped to shift policy debates away from the hitherto prevalent 'us' and 'them' discourse, which is certain to change perceptions about citizenship in the medium term.

However, in the meantime, Germany will continue to grapple with the challenge not just of making access to its citizenry easier in principle, but also of achieving this in practice. Important as the post-2000 increases in naturalisation are, the baseline is so low that, on current trends, the non-national population in Germany will remain broadly constant in size, it will be increasingly well-settled and, especially among the older group of first generation immigrants, effectively permanently excluded from political participation. Of course, it is a moot point whether it is incumbent on non-nationals to seek naturalisation so that they can participate, or on the host state to ensure that this is an attractive option to them. But this misses the key point that Germany as a country and a polity loses far more in terms of legitimacy than individual non-nationals do through non-participation in the political process. That being the case, the debate over the content, direction and impact of Germany's citizenship legislation looks set to remain on the agenda for some years yet. 


\section{References:}

Bauböck, R., Ersbøll, E., Groenendijk, K. and Waldrauch, H., 2006. Acquisition and Loss of Nationality. Politicies and Trends in 15 European States (2 vols). Amsterdam: Amsterdam University Press

Beauftragte der Bundesregierung für Migration, Flüchtlinge und Integration, 2007. 7. Bericht der Beauftragten der Bundesregierung für Migration, Flüchtlinge und Integration über die Lage der Ausländerinnen und Ausländer in Deutschland. Berlin: Beauftragte der Bundesregierung

Brubaker, W., ed., 1989. Immigration and the Politics of Citizenship in Europe and North America. Lanham, MD: University Press of America

Brubaker, R., 1992. Citizenship and Nationhood in France and Germany. Cambridge, MA: Harvard University Press

Bundesministerium des Innern, 2009. Vorläufige Anwendungshinweise des Bundesministeriums des Innern zum Staatsangehörigkeitsgesetz in der Fassung des Gesetzes zur Änderung des Staatsangehörigkeitsgesetzes vom 5. Februar 2009 (BGBl. I S. 158). Berlin: BMI. Available at:

http://www.bmi.bund.de/cln_165/SharedDocs/Standardartikel/DE/Themen/MigrationIntegrati on/Staatsang/VorlaeufigeAnwendungshinweise.html?nn=257720 (accessed 1 April 2010) 
Bundestagsdrucksache 16/13558, available via http://www.bundestag.de/dokumente/index.jsp (accessed 2 March 2010)

Davy, U. 2005, Integration of Immigrants in Germany: A Slowly Evolving Concept. European Journal of Migration and Law, 7, 123-144

Deutscher Bundestag Plenarprotokoll 14/40 (7 May 1999) and 16/221 (13 May 2009), available via http://www.bundestag.de/dokumente/index.jsp (accessed 1 April 2010).

Dornis, C., 2002. Zwei Jahre nach der Reform des Staatsangehörigkeitsrecht - Bilanz und Ausblick. In K. Bade and R. Münz, eds. Migrationsreport 2002. Fakten - Analysen Perspektiven. Frankfurt: Campus.

Faist, T., 1994. How to define a foreigner? The symbolic politics of immigration in German partisan discourse, 1978-1992. West European Politics, 17 (2), 50-71

Goodman, S., 2010. Integration Requirements for Integration's Sake? Identifying, Categorising and Comparing Civic Integration Policies. Journal of Ethnic and Migration Studies, $36(5), 753-72$

Green, S., 2000. Beyond Ethnoculturalism? German Citizenship in the New Millennium. German Politics, 9(3), 105-124

Green, S., 2004. The Politics of Exclusion: Institutions and Immigration Policy in Contemporary Germany. Manchester: Manchester University Press. 
Green, S., 2005. Between Ideology and Pragmatism: The Politics of Dual Nationality in Germany. International Migration Review, 39 (4), 921-952.

Hagedorn, H., 2001. Wer darf Mitglied werden? Einbürgerung in Deutschland und Frankreich im Vergleich. Opladen: Leske + Budrich.

Hailbronner, K., 1989. Citizenship and Nationhood in Germany. In W. Brubaker, ed. Immigration and the Politics of Citizenship in Europe and North America. Lanham, MD: University Press of America.

Hansen, R., 2000. Citizenship and Immigration in Post-War Britain. Oxford: Oxford University Press

Hansen, R. and Koehler, J., 2005. Issue definition, political discourse and the politics of nationality reform in France and Germany. European Journal of Political Research, 44, 623644

Hansen, R. and Weil, P., eds., 2001. Towards a European Nationality: Citizenship, Immigration and Nationality Law in the EU. Basingstoke: Palgrave.

Hofhansel, C., 2008. Citizenship in Austria, Germany, and Switzerland: Courts, Legislatures, and Administrators. International Migration Review, 42 (1), 163-192 
Howard, M., 2005. Variation in Dual Citizenship Policies in the Countries of the EU.

International Migration Review, 39 (3), 697-720

Howard, M., 2008. The Causes and Consequences of Germany's New Citizenship Law.

German Politics, 17 (1), 41-62

Howard, M., 2009. The Politics of Citizenship in Europe. Cambridge: Cambridge University Press

Jacobsen, D., 1996. Rights across Borders. Immigration and the Decline of Citizenship. Baltimore: Johns Hopkins University Press

Joppke, C., 1999. Immigration and the Nation State. Oxford: Oxford University Press

Joppke, C., 2007. Beyond national models: Civic integration policies for immigrants in Western Europe. West European Politics, 30 (1), 1 - 22

Joppke, C., 2010. Citizenship and Immigration. Cambridge: Polity Press

Klusmeyer, D. and Papademetriou, D., 2009. Immigration Policy in the Federal Republic of Germany: Negotiating Membership and Remaking the Nation. Oxford: Berghahn.

Lämmermann, F., 2009. Einbürgerung - Aktuelle Entwicklungen und Perspektiven.

Zeitschrift für Ausländerrecht, 9/2009, 289-296 
Migration und Bevölkerung, Issue 1/2006. Deutschland: Streit um Einbürgerungsleitfaden. Available via www.migration-info.de (accessed 1 April 2010)

Palmowski, J., 2008. In search of the German nation: citizenship and the challenge of integration. Citizenship Studies, 12 (6), 547-563

Renner, G., 1999. Was ist neu am neuen Staatsangehörigkeitsrecht? Zeitschrift für Ausländerrecht, 4/1999, 154 - 163

Sassen, S., 1996. Losing control: sovereignty in an age of globalization. New York: Columbia University Press

Soysal, Y., 1994. Limits of Citizenship. Migrants and Postnational Membership in Europe. Chicago: University of Chicago Press.

Spindler, H., 2002. Das neue Staatsangehörigkeitsrecht. In H. Storz and C. Reißlandt (eds.), Staatsbürgerschaft im Einwanderungsland Deutschland. Opladen: Leske + Budrich. Staatsangehörigkeitsgesetz (StAG) of 22 July 1913, in the amended form of 5 February 2009. Available at http://bundesrecht.juris.de/bundesrecht/rustag/gesamt.pdf (accessed 1 April 2010)

Statistisches Bundesamt, 2009. Statistisches Jahrbuch 2009. Wiesbaden: Statistisches Bundesamt. Available at https://wwwec.destatis.de/csp/shop/sfg/bpm.html.cms.cBroker.cls?cmspath=struktur,vollanzeige.csp\&ID= $\underline{1024348}$ (accessed 10 July 2010) 
Statistisches Bundesamt, 2010. Bevölkerung und Erwerbstätigkeit: Einbürgerungen 2009. Fachserie 1 Reihe 2.1. Wiesbaden: Statistisches Bundesamt. Available at https://wwwec.destatis.de/csp/shop/sfg/bpm.html.cms.cBroker.cls?cmspath=struktur,sfgsuchergebnis.csp

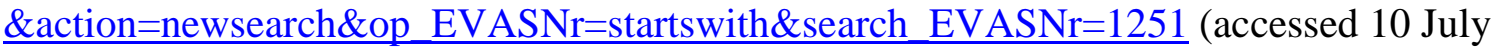
2010).

Topçu, C., 2007. EinBÜRGERung. Lesebuch über das Deutsch-Werden. Portraits, Interviews, Fakten. Frankfurt: Brandes und Aspel

Vink, M. and de Groot, G.-R., 2010. Citizenship Attribution in Western Europe: International Framework and Domestic Trends, Journal of Ethnic and Migration Studies, 36 (5), 713-34

Weil, P., 2008. How to Be French: Nationality in the Making since 1789. Durham, NC: Duke University Press

Worbs, S., 2008. Die Einbürgerung von Ausländern in Deutschland. Working Paper 17 der Forschungsgruppe des Bundesamtes für Migration und Flüchtlinge. Nürnberg: BAMF. Available at http://www.bamf.de/cln_170/SharedDocs/Anlagen/DE/Migration/Publikationen/Forschung/W orkingPapers/wp17-einbuergerung,templateId=raw,property=publicationFile.pdf/wp17einbuergerung.pdf (accessed 1 April 2010)

Wunderlich, T., 2005, Die neuen Deutschen. Subjektive Dimensionen des Einbürgerungsprozesses. Stuttgart: Lucius \& Lucius. 
Wüst, A., 2004, Naturalised Citizens as Voters: Behaviour and Impact. German Politics, 13 (2), $341-359$ 
Figure 1: Naturalisations in Germany, 1990-2009

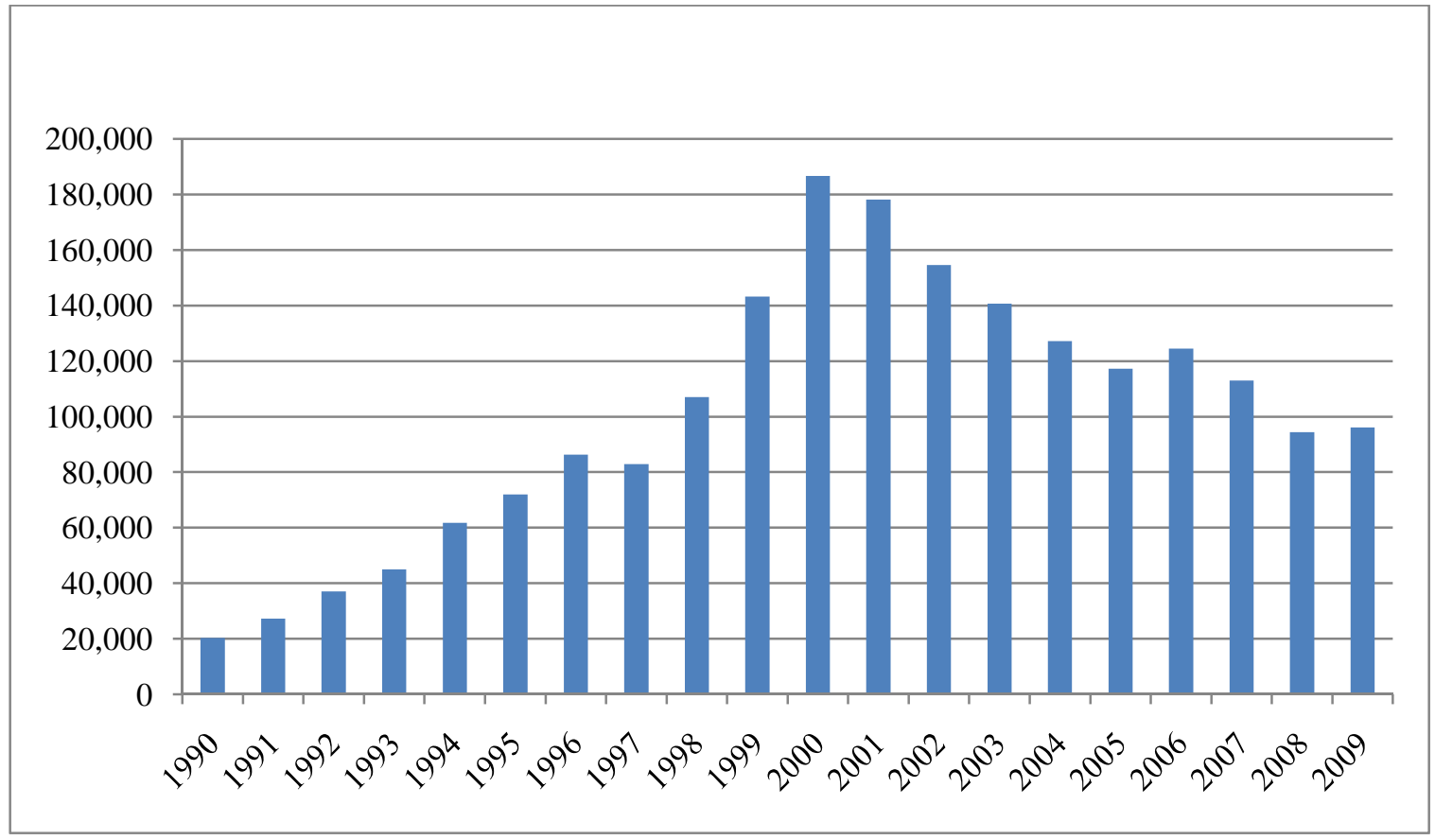

Note: Figures exclude naturalisations of ethnic Germans.

Source: Statistisches Bundesamt

Figure 2: Toleration of dual citizenship, 1997-2009

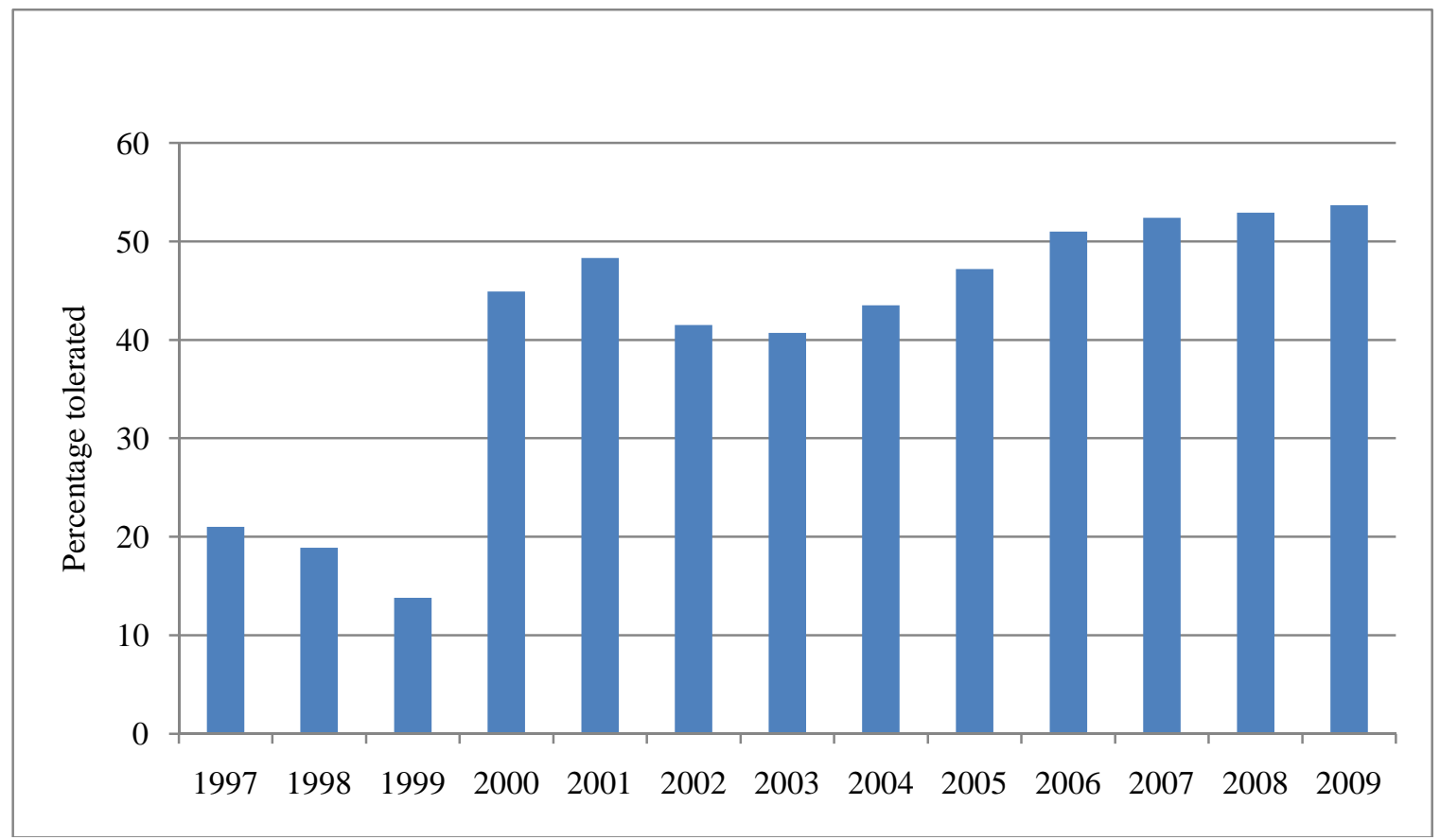

Source: Statistisches Bundesamt 
Acknowledgement: I would like to thank Marc Morjé Howard and an anonymous reviewer for their helpful comments on an earlier version of this article.

Author note: Simon Green is Professor of Politics and Co-Director of the Aston Centre for Europe at Aston University. His research interests include citizenship policy in Europe and German politics. Most recently, he has co-authored the second edition of The Politics of the New Germany (Routledge).

Notes:

${ }^{1}$ In 2004, a recalculation of the available data was undertaken by the Federal Statistical Office (Statistisches Bundesamt), as a result of which the number of non-nationals was adjusted downwards by some 600,000 persons. Before 2004, the number of non-national residents was 7.3 million, a figure which itself had remained stable since 1996. See Statistisches Bundesamt (2010, p. 15).

${ }^{2}$ It should not of course be forgotten that individual applicants may not have been eligible for naturalisation due to other factors, such as the requirement to be able to provide for oneself.

${ }^{3}$ All direct translations from the German are the author's.

${ }^{4}$ The 2007 reform was not actually a separate legislative process, but occurred in the context of the transposition of eleven EU directives into German law.

${ }^{5}$ Of course, this principle also applies to children born to mixed nationality (German) parentage abroad. It is likely that this figure will add several hundred thousand more persons to the total. 